\title{
Influence of management control systems and creativity on job performance
}

\author{
ITZHAK DAVID SIMÃO KAVESKI ${ }^{1}$ \\ ILSE MARIA BEUREN ${ }^{2}$ \\ ${ }^{1}$ Universidade Federal de Mato Grosso do Sul (UFMS), Corumbá - MS, Brazil \\ ${ }^{2}$ UniVERsidAde FEDERAL DE SANTA CATARINA (UFSC), FLORIANÓPOLIS - SC, BRAZIL
}

\begin{abstract}
This study analyzes the influence of managerial control systems (MCS) on job performance, mediated by individual creativity. Simons's (1995) four levers of control were considered: belief systems, boundary systems, interactive control systems, and diagnostic control systems. A survey was conducted with industrial companies considered to be innovative in Brazil, obtaining 126 valid responses. The results of the structural equation modeling indicated a significantly different relationship between MCS and individual creativity. Some positively influence belief systems and interactive control systems, while others negatively influence diagnostic control systems. It was also found that belief systems positively influence job performance, partly mediated by individual creativity. These results denote the importance of MCS to stimulate managers' individual creativity, to assist in tasks carried out in the organization and, to increase job performance. The study concludes that belief systems, interactive control systems, and diagnostic control systems influence individual creativity, just as creativity influences job performance. In addition, the non-significance of the relationship between boundary systems and individual creativity deserves further research.
\end{abstract}

Keywords: Management control systems. Job performance. Creativity.

\section{Influência dos sistemas de controle gerencial e da criatividade sobre o desempenho no trabalho \\ Resumo}

Este estudo analisa a influência dos sistemas de controle gerencial (SCG) sobre o desempenho no trabalho, mediada pela criatividade individual. Foram consideradas as quatro alavancas de controle do modelo de Simons (1995): sistemas de crenças, sistemas de limites, sistemas de controle interativo e sistemas de controle diagnóstico. Uma pesquisa de levantamento foi realizada com empresas industriais consideradas inovadoras no Brasil, e obteve-se um retorno de 126 respostas válidas. Os resultados da modelagem de equações estruturais indicaram que há relações significativamente diferentes entre os SCG e a criatividade individual: algumas influenciam positivamente os sistemas de crenças e os sistemas de controle interativo; enquanto outras influenciam negativamente os sistemas de controle diagnóstico. Averiguou-se ainda que os sistemas de crenças influenciam de forma positiva o desempenho no trabalho, mediados de forma parcial pela criatividade individual. Estes resultados denotam a importância dos SCG para estimular a criatividade individual dos gestores, para auxiliar na realização das tarefas na organização e, consequentemente, aumentar o desempenho no trabalho. Conclui-se que os sistemas de crenças, os sistemas de controle interativo e os sistemas de controle diagnóstico influenciam na criatividade individual, tal como a criatividade influencia no desempenho no trabalho. Por fim, considera-se que a não significância da relação entre sistemas de limites e criatividade individual instiga novas pesquisas.

Palavras-chave: Sistemas de controle gerencial. Desempenho no trabalho. Criatividade.

\section{Influencia de los sistemas de control de gestión y creatividad sobre el desempeño en el trabajo}

\section{Resumen}

Este estudio analiza la influencia de los sistemas de control de gestión (SCG)) sobre el desempeño en el trabajo, mediada por la creatividad individual. Se consideraron las cuatro palancas de control del modelo de Simons (1995): sistemas de creencias, sistemas de límites, sistemas de control interactivo y sistemas de control de diagnóstico. Se realizó una encuesta con empresas industriales consideradas innovadoras en Brasil, y se obtuvieron 126 respuestas válidas. Los resultados del modelado de ecuaciones estructurales indicaron que hay relaciones significativamente diferentes entre SCG y la creatividad individual: algunas influyen positivamente en los sistemas de creencias y los sistemas de control interactivo; mientras que otras influyen negativamente en los sistemas de control diagnóstico. También se averiguó que los sistemas de creencias influyen positivamente en el desempeño en el trabajo, mediados de forma parcial por la creatividad individual. Estos resultados denotan la importancia de los SCG para estimular la creatividad individual de los gestores, para auxiliar en la realización de las tareas en la organización y, consecuentemente, aumentar el desempeño en el trabajo. Se concluye que los sistemas de creencias, sistemas de control interactivo y sistemas de control diagnóstico influencian en la creatividad individual, tal como la creatividad influye en el desempeño del trabajo. Por fin, se considera que la no significancia de la relación entre sistemas de límites y creatividad individual instiga nuevas investigaciones.

Palabras clave: Sistemas de control de gestión. Desempeño en el trabajo. Creatividad. 


\section{INTRODUCTION}

Management control systems (MCSs) incorporate all the systems used by managers to ensure the congruence of subordinate decisions and behavior with the organizational strategies and objectives (MERCHANT and VAN DER STEDE, 2017). They are designed in a format so that employees accept the objectives of the organization, according to pre-established standards and plans, and, at the same time, are obliged to sacrifice their individual interests to achieve what has been pre-established by the company (ADLER and CHEN, 2011). In this sense, several studies have focused on understanding how the MCSs influence individual and/or organizational performance (HALL, 2011).

Some research has linked MCS to work performance, for example, Burney and Widener (2007), Hall (2008, 2011), Marginson, McAulay, Roush et al. (2014). These studies highlight the role of cognitive (role clarity) and motivational (psychological empowerment) mechanisms to understand how the MCSs affect individual performance. There is a gap in the examination of the direct and/or indirect effects of the components of the MCSs on work performance. However, there may be theoreticalempirical differences between the models of direct and indirect effects (HALL, 2008).

Another aspect that has received attention in this context is the individual creativity, identified as essential in the organization's capacity to innovate in order to remain competitive (AMABILE, 1983; DAVILA, FOSTER and OYON, 2009). Thus, the MCSs can be used either to generate or to restrict creativity in the organization (AMABILE, 1983; DAVILA, FOSTER and OYON, 2009). That is, on the one hand, the restriction of creativity by the MCSs consists of implementing a standardization that restricts creativity (MOULANG, 2015); on the other hand, the stimulus of creativity by the MCSs consists of changing the patterns of the organizational activities, encouraging creativity and the search for new opportunities (SIMONS, 1995).

Davila, Foster and Oyon (2009) highlight that individual creativity can be stimulated in work environments strongly influenced by the MCSs. However, they defend the need for more research on individual creativity. According to Gong, Huang and Farh (2009), individual creativity can be beneficial to the results at work, which is likely to benefit the organizations. However, Gilson (2008) warns that this creativity cannot negatively impact the individual's work performance. He argues that there is a need for further empirical studies to ascertain whether individual creativity results in better individual performance in the organizational environment.

Based on the above, this is the question that guides this study: what is the influence of the management control systems (belief systems, boundary systems, interactive control systems and diagnostic control systems) on work performance (individual performance) manager in the company), mediated by individual creativity (involvement of the manager with creative activities in the company)? Thus, the objective of the present study is to verify the influence of the management control systems on work performance, mediated by individual creativity.

Previous research, such as Webster (2006) and Moulang (2015), considered only interactive control systems, while other research, such as Speklé, Van Elten and Widener (2017), considered Simons' four levers jointly. Besides, these research used psychological empowerment as a mediating variable between individual creativity and MCS. The herein study contributes to the theoretical framework of the problem by analyzing Simons' four levers separately and considering individual creativity as a mediator between the MCSs and work performance.

This study is justified by investigating the antecedents and consequences of individual creativity, that is, what makes an individual creative to benefit their tasks and the organization as a whole (ZHOU and SHALLEY, 2008; GONG, HUANG and FARH, 2009). Therefore, it presents a different perspective of the relationship between the MCSs and work performance, using individual creativity as a mediating variable. It also differs from the research that examined how cognitive and motivational mechanisms explain the relationships between the MCSs and work performance (BURNEY and WIDENER, 2007; HALL, 2008, 2011; MARGINSON, MCAULAY, ROUSH et al., 2014), by investigating how the MCSs can improve the individual performance of the managers through their creativity.

The study is also justified by considering the MCSs, with Levers of Control (LOCs) of Simons' model (1995), as antecedents of individual creativity. It was chosen to Simons' model (1995) in this study because, in order to deal with the tension between the need to achieve the established goals and expand the search for new opportunities, innovation and strategic initiatives, managers use the four levers of control, which create dynamic tensions and guarantee the control of the organization. 


\section{THEORETICAL FRAMEWORK AND RESEARCH HYPOTHESES}

The literature points to the MCSs as antecedents of creativity and performance, as they aim to balance the dynamic tensions arising from the organizational need to grant freedom for the development of individuals' creativity and, at the same time, ensure the control of resources, considering that these relationships emerge in an environment of intense competition (SIMONS, 1995). Thus, this section presents a theoretical framework on the relationship between the MCSs, creativity and performance, in addition to formulating the three research hypotheses.

\section{Management control systems and creativity}

Anthony (1965) coined the concept of Management Control System (MCS) to describe the totality of formal processes and institutions that allow management to control the use of resources so that the organizational goals and strategies are respectively met and implemented. According to Simons (1995), the MCSs consist of routines and procedures based on information that are used by managers to influence organizational activities.

Simons (1995) proposed a MCS model composed of four Levers of Control (LOCs): (i) belief systems, responsible for providing fundamental values of the organization such as mission, vision and values to its members; (ii) boundary systems, responsible for outlining members' acceptable behavior in the organization; (iii) interactive control systems, responsible for promoting and enabling face-to-face involvement between subordinates and peers; and (iv) diagnostic control systems, responsible for following, monitoring and evaluating members' performance. Simons (1995) postulates that the MCSs can be used jointly by managers.

Research such as Webster (2006), Moulang (2015) and Speklé, Van Elten and Widener (2017) investigated the MCS as an antecedent of creativity in organizations. They analyzed the extent to which the MCS can favor or inhibit creativity in organizations. Creativity is understood as the generation of new and useful ideas by an individual or small group of individuals (AMABILE, 1983). It is manifested by the creative performance of an individual in the elaboration of useful ideas related to products, services, tasks, methods or procedures (ZHANG and BARTOL, 2010).

Creativity is essential for an organization's innovative capacity, which can be both beneficial to the individual work performance and to the overall result of the organization (GEORGE and ZHOU, 2002; GONG, HUANG and FARH, 2009). In turn, the MCSs can be used to increase or restrict this creativity in organizations (MOULANG, 2015), granting freedom for their development through the individuals and, at the same time, ensure the control of resources.

Webster (2006) explored the nature of the relationships between the interactive use of the MCSs and the results of creativity through the individual performance of managers in Australian organizations. His study showed that the interactive use of the MCSs can stimulate feelings associated with psychological empowerment and, consequently, increase creativity and individual performance. He concluded that the MCSs have the potential to stimulate creativity, but he recognizes the difficulty of measuring creativity, which represents a research gap.

Moulang (2015) developed a conceptual framework to relate the use of the MCSs to creativity, incorporating psychological empowerment as a mediating variable. The results show that psychological empowerment helps to explain the relationship between the interactive use of the MCSs and creativity. The author concluded that the interactive use of the MCSs affects the individuals' psychological processes, their cognitions of psychological empowerment, and that the psychological empowerment affects their creativity providing alternative and potentially more creative responses in the performance of tasks.

Speklé, Van Elten and Widener (2017) developed a theoretical model based on Simons' LOCs (1995) to investigate the paradox between individual creativity and MCSs, mediated by psychological empowerment. The results of the study showed that the LOCs provide information to employees about the organization's problems: they show organizational issues that demand creative action, act as motivating agents in decision-making and provide employees with the freedom to be creative within a certain limit. In this way, the authors argue that it is relevant to identify the influence of the MCSs on, and psychological empowerment on creativity, since this scenario permeates the environment with dynamic tension, necessary for creativity in the presence of MCSs.

It is possible to infer from the above that the diversity of dimensions related to creativity in the organizational scope may have influenced the conflicting results of the research. Thus, the first hypothesis is formulated:

- $\mathrm{H}_{1}$ : There is a positive relationship between the management control systems and individual creativity. 
The confirmation of hypothesis $\mathrm{H}_{1}$ will indicate that the MCSs are an antecedent element of individual creativity, raising the individual creativity of managers. In this case, managers can use the MCSs to increase individual creativity in the organizations.

\section{Creativity and work performance}

Creativity is made up of expertise, creative thinking and motivation to perform a task (AMABILLE, 1983). Expertise is the beginning of all creative work (AMABILLE, 1983) and refers to the knowledge of a certain domain, which is influenced by the individual's formal and informal education, in addition to their motor, cognitive and perceptual skills (ZHOU and SHALLEY, 2008). Creative thinking adds value to creative performance and opens new perspectives for problem solving, based on the persistence of the evolution of something that already exists (ZHOU and SHALLEY, 2008). Motivation to perform a task comprises the individual's attitude in accomplishing a certain task and the perception of his motivation to perform it (ZHOU and SHALLEY, 2008). It can be intrinsic, arising from an individual's positive reaction to the quality of performing a task, or extrinsic, when motivation comes from sources external to the task (AMABILLE, 1983; ZHOU and SHALLEY, 2008).

Organizationally, these aspects influence work performance. Creative employees tend to be more capable of solving problems, which is reflected in higher levels of performance (GONG, HUANG and FARH, 2009). This is corroborated by Gong, Huang and Farh (2009), who investigated the relationship between employees' creativity and their work performance, as measured by the supervisors and the sales numbers. Among the results, it was found out that the employees' creativity is positively related to work performance. Such results denote the importance of the individuals' creativity in the organizations to improve their work performance, the performance of the work unit and / or of the organization as a whole.

Creativity, understood as a construct of creative performance, was related to work performance in the research carried out by Zhang and Bartol (2010), and Bodla and Naeem (2014). Zhang and Bartol (2010) investigated broader issues of the relationship between engagement in the creative work process, creative performance and work performance, and found out a partial mediation in the relationship between creative performance and work performance. Bodla and Naeem (2014) developed a theoretical framework to verify the influence of intrinsic motivation on sales performance using creative performance as a partial mediator, and they observed that the creative performance of the sales force is fueled by intrinsic motivation.

Based on the above, where creativity is approached as a predictor of work performance, the second research hypothesis is:

- $\mathrm{H}_{2}$ : There is a positive relationship between individual creativity and work performance.

The confirmation of hypothesis $\mathrm{H}_{2}$ will indicate that managers who seek new ideas in the provision of services, or who excel in improving the processes and procedures of the tasks, manage to improve the quality and effectiveness of the service.

\section{Management control systems and work performance}

The effects of the MCSs on the workers' individual performance have been analyzed in different contexts. The results of the research reveal that the MCSs indirectly influence the performance of managers through mediation variables, such as ambiguity of roles (BURNEY and WIDENER, 2007; MARGINSON, MCAULAY, ROUSH et al., 2014), conflict of roles and information relevant to the work (BURNEY and WIDENER, 2007), psychological empowerment (HALL, 2008; MARGINSON, MCAULAY, ROUSH et al., 2014), clarity of roles (HALL, 2008) and development of managers' mental models (HALL, 2011).

Burney and Widener (2007) examined the mediating effect of the role conflict, the ambiguity of roles and information relevant to the work in the relationship between the MCSs and managerial performance. The result was based on data collected from more than 700 members of the Institute of Management Accountants (IMA) in managerial positions. The research shows that the relationship between the MCSs and managerial performance is mediated by information relevant to the work, the ambiguity of roles and the conflict of roles. MCSs intensify information relevant to the development of managers' work and reduce ambiguity and role conflicts, thus contributing to increase their performance. 
Hall (2008) investigated how the MCSs affect management performance, with the premise that the MCSs can help improve the managerial performance of the organization's employees, but that this effect is indirect, mediated by variables such as psychological empowerment and the clarity of roles at work. The survey sample comprised 83 strategic managers of Australian business units. The results showed that the MCSs are indirectly related to managerial performance, due to the intervening variables psychological empowerment and clarity of roles at work. The study carried out by Hall highlights the role of the cognitive and motivational mechanisms in explaining the effects of the MCSs on managerial performance.

Subsequently, Hall (2011) analyzed how the learning and development of the managers' mental model helps to explain how the MCSs affect their individual performances. In order to do that, he investigated a sample of 81 managers of Australian business units and noticed that more comprehensive MCSs help in the learning and development of managers' mental models, but only for those who are new to the organization and/or who work in small companies. Thus, he concluded that the MCSs, mediated by learning and the development of the mental model, positively influence the individual performance of the managers.

Marginson, McAulay, Roush et al. (2014) investigated the impacts of psychological empowerment and the ambiguity of roles in performance evaluation measures, specifically the psychological consequences of the use of interactive and diagnostic control systems on managerial performance. The results showed that the role ambiguity is negatively impacted by the diagnostic and interactive use, in addition to negatively affecting the management performance. It indicates that the diagnostic use and the interactive use are effective sources of information to neutralize role ambiguity and generate positive psychological experience and self-determination and, indirectly, to improve performance.

Based on the arguments presented and the results of the theoretical-empirical research aforementioned, the third research hypothesis was formulated:

- $\mathrm{H}_{3}$ There is a positive relationship between management control systems and work performance, mediated by individual creativity.

The confirmation of hypothesis $\mathrm{H}_{3}$ will indicate that the MCSs positively and indirectly influence the individual performance of the managers. Thus, managers can benefit from the MCSs and individual creativity to improve their performance.

Figure 1 presents the theoretical model of the research with the hypotheses formulated.

Figure 1

Theoretical model of the research

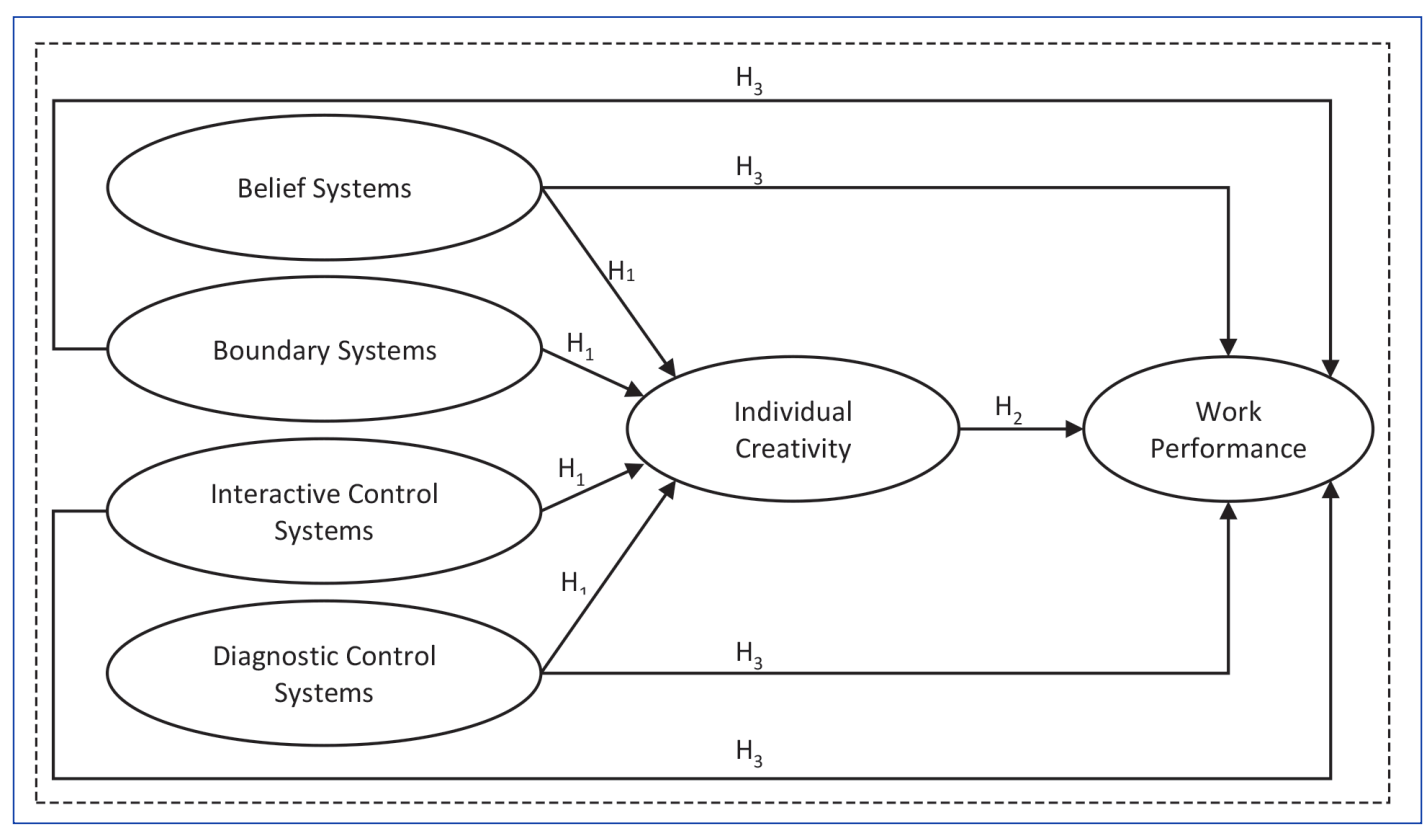

Source: Elaborated by the authors. 
In accordance with the theoretical model of the research, it is conjectured that: the MCSs positively influence individual creativity, since they allow fostering managers' individual creativity; that individual creativity has a positive effect on work performance, which will indicate that managers who use new ideas in the provision of services, or who consider improvements in the processes and procedures of the tasks improve the quality of the service and its effectiveness; and that individual creativity can mediate the effects of the MCSs on work performance.

\section{METHODOLOGICAL PROCEDURES}

Survey research was carried out with industrial companies considered innovative in Brazil, affiliated to the National Association of Research and Development of Innovative Companies (Associação Nacional de Pesquisa e Desenvolvimento das Empresas Inovadoras - ANPEI). An invitation was sent by LinkedIn to the managers registered on the innovative companies' link. The terms managers, directors and coordinators were used in the search process. Among the 500 invitations sent to compose the social network, 350 were accepted by the managers, to whom the survey instrument was sent by the SurveyMonkey platform, in the period from February to June 2017, and a total of 126 valid questionnaires were returned.

The sample size was calculated using the G*Power software, which implies "[...] evaluating the construct or latent variable that receives the greatest number of arrows or has the greatest number of predictors" (RINGLE, SILVA and BIDO, 2014, p. 58). The theoretical model consists of four exogenous latent variables (diagnostic control systems, interactive control systems, boundary systems and belief systems) and a mediator (individual creativity). The effect size used was 0.15 , the significance level of $\alpha$ was 0.05 , the power of 1- 6 sample was 0.8 , with five predictors. The minimum sample required for the model was 92 respondents.

\section{RESEARCH CONSTRUCTS AND INSTRUMENT}

Box 1 presents the research constructs, the respective assertions and the references that supported both.

Box 1

Research Construct

\begin{tabular}{|c|c|}
\hline Constructs & Assertions \\
\hline \multirow{4}{*}{$\begin{array}{l}\text { Belief Systems } \\
\text { (WIDENER, 2007) }\end{array}$} & 1. Our mission statement clearly communicates the company's core values to our workforce. \\
\hline & 2. Top managers communicate the company's core values to our workforce. \\
\hline & 3. Our workforce is aware of the company's core values. \\
\hline & 4. Our mission statement inspires our workforce. \\
\hline \multirow{4}{*}{$\begin{array}{l}\text { Boundary Systems } \\
\text { (WIDENER, 2007) }\end{array}$} & $\begin{array}{l}\text { 1. Our company is based on a corporate code of conduct to define the appropriate behavior for our } \\
\text { workforce. }\end{array}$ \\
\hline & 2. Our code of business conduct informs our workforce about behaviors that are off limits. \\
\hline & 3. Our company has a system that communicates to our workforce risks that must be avoided. \\
\hline & 4. Our workforce is aware of our code of business conduct. \\
\hline \multirow{4}{*}{$\begin{array}{c}\text { Interactive Control } \\
\text { Systems } \\
\text { (HENRI, 2006) }\end{array}$} & 1. Promote discussions in meetings between superiors, subordinates and peers. \\
\hline & 2. Enable the ongoing challenge and discuss the underlying data, assumptions and action plans. \\
\hline & 3. Enable the organization to focus on common issues. \\
\hline & 4. Enable the organization to focus on critical success factors. \\
\hline
\end{tabular}




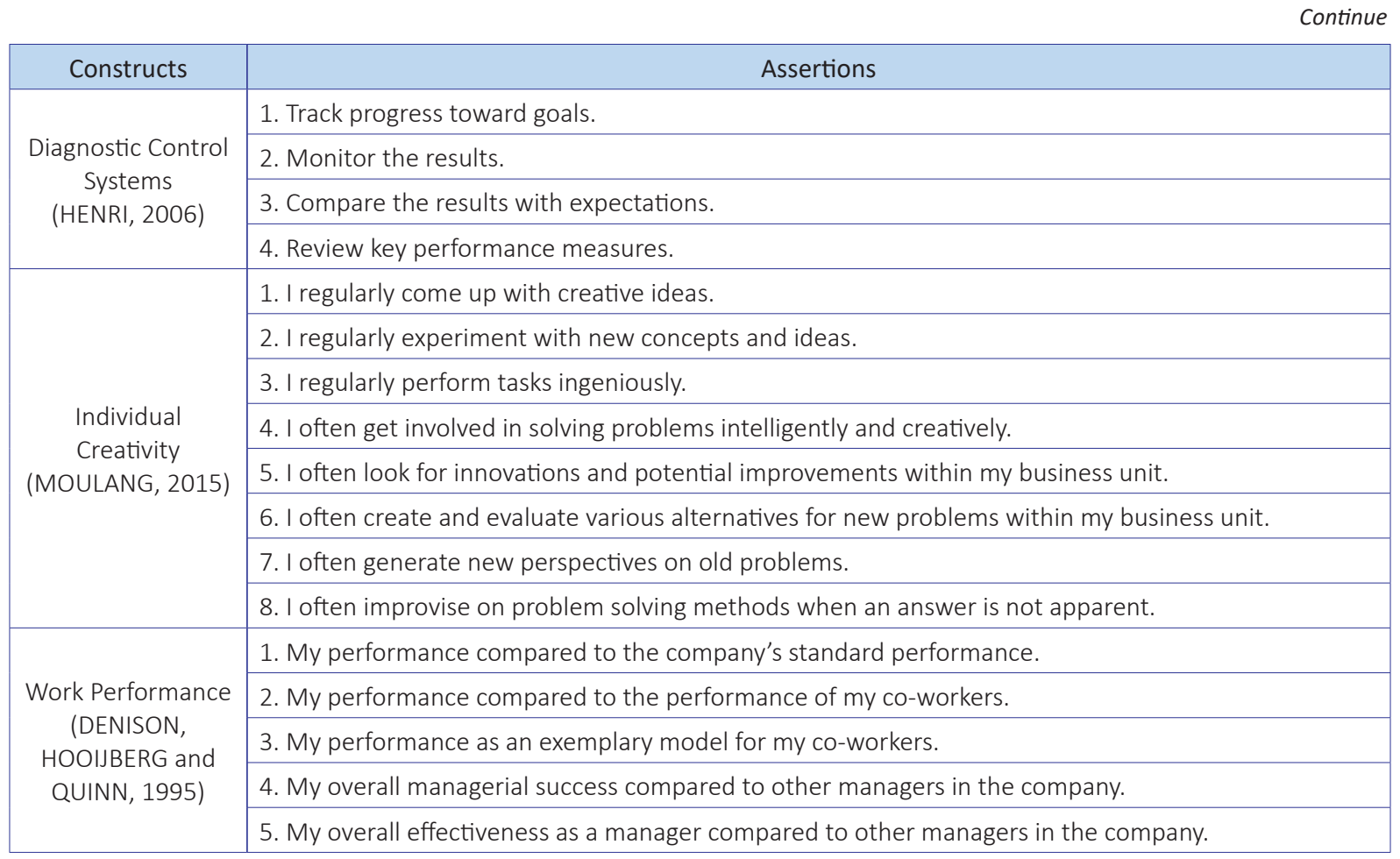

Source: Elaborated by the authors.

After being translated to Portuguese, the assertions in Box 1 were again translated into English in order to assure their correct translation. The research instrument was initially submitted to the evaluation of two doctoral students and a researcher in accounting who suggested some adjustments to the wording. The questionnaire was structured in three parts.

MCSs are made up of Simons' four levers (1995). As for belief systems, the goal was to assess the extent to which the assertions describe the organization's systems, being $1=$ not very descriptive and $7=$ very descriptive. Regarding boundary systems, the goal was to assess the degree of agreement with the assertions about this system, being $1=$ strongly disagree and 7 = strongly agree. As for the assertions about the interactive and diagnostic control levers, the goal was to assess the extent to which managers use performance measures, being $1=$ to a small extent and $7=$ to a large extent.

Individual creativity consists of eight assertions from the questionnaire proposed by Moulang (2015) that assessed the extent to which managers are involved in certain creative activities in the organization. Regarding this matter, the goal was to assess the extent to which the situations described in the questionnaire characterize the respondent's creativity in the organization, being $1=$ almost never and $7=$ almost always.

The measurement of work performance consists of five assertions from the questionnaire proposed by Denison, Hooijberg and Quinn (1995) that assess the manager's work performance in situations in the organization. It is a measure of selfassessment of performance and is commonly used to measure individual performance (WEBSTER, 2006). This instrument had two adaptations: first, on the scale used - the original was a five point scale and the herein study used a seven point scale to align with the other questions; and second, in the presentation of the assertions - the original offered a contextualization for each question, while in the one used in the herein study presents a general statement. In these assertions, the goal was to assess the extent to which the work performance of the respondents is consistent with the situations mentioned, being $1=$ very low and $7=$ very high. 


\section{DATA ANALYSIS PROCEDURES}

Structural Equation Modeling (SEM) was applied to test the hypotheses, using the statistical software SmartPLS version 3. SEM is a test technique for theoretically estimated models. Partial Least Square (PLS) was used as the adjustment method, recommended for studies with non-normal data distribution, and less demanding in terms of sample size compared to the maximum likelihood (HAIR JUNIOR, HULT, RINGLE et al., 2014).

PLS-SEM was used because it is an adequate technique for studies that have small samples (CHIN, 1998). The analysis of the PLS-SEM is carried out in two stages: the first deals with the validity of the constructs adequacy, through the relationship between the indicators and the latent variables or constructs, and allows the researcher to assess the reliability and validity of the latent variables or constructs; the second deals with the relationship between latent variables or constructs, and allows verifying whether an exogenous latent variable is related to an endogenous latent variable (HAIR JUNIOR, HULT, RINGLE et al., 2014).

\section{DESCRIPTION AND ANALYSIS OF RESULTS}

\section{Measurement model}

Initially, the validity of the constructs adequacy was tested, assessing the internal consistency reliability (composite reliability and Cronbach's alpha), the discriminant validity (cross-loadings and Forell-Larcker test) and the convergent validity. The internal consistency reliability provides the reliability of the index within the latent variables; discriminant validity is the extent to which a latent variable appears to be distinct from other latent variables by empirical patterns; and convergent validity is the extent to which an index correlates positively with alternative indexes of the same latent variable (HAIR JUNIOR, HULT, RINGLE et al., 2014).

The first discriminant validity test performed was cross-loadings, in which the factor loads of the questions must be greater in their related latent variable than in the other ones (HAIR JUNIOR, HULT, RINGLE et al., 2014). Question 8 of the construct individual creativity had a low factor load $(0.427)$ being, therefore, removed from the construct. Thus, all the questions regarding the latent variables were adequate for the model, with no need to remove any more questions, with factor load values above 0.70 (CHIN, 1998).

After this analysis, Cronbach's Alpha and Composite Reliability tests were used to assess the internal consistency of the model, and Average Variance Extracted (AVE) test was used to assess the convergent validity. The results are shown in Table 1.

Table 1

Composite Reliability, Cronbach's Alpha, Convergent e Discriminant Validity

\begin{tabular}{|c|c|c|c|c|c|c|c|c|c|}
\hline \multirow[b]{2}{*}{ Variables } & \multirow{2}{*}{$\begin{array}{c}\text { Composite } \\
\text { Reliability } \\
>0,70\end{array}$} & \multirow{2}{*}{$\begin{array}{c}\text { Cronbach's } \\
\text { Alpha } \\
>0,70\end{array}$} & \multirow{2}{*}{$\begin{array}{c}\text { AVE } \\
>0,50\end{array}$} & \multicolumn{6}{|c|}{ Discriminant Validity } \\
\hline & & & & IC & WP & DCS & ICS & BS & LS \\
\hline Individual Creativity (IC) & 0,915 & 0,892 & 0,608 & 0,780 & & & & & \\
\hline $\begin{array}{l}\text { Work Performance } \\
\text { (WP) }\end{array}$ & 0,927 & 0,902 & 0,718 & 0,569 & 0,847 & & & & \\
\hline $\begin{array}{l}\text { Diagnostic Control S. } \\
\text { (DCS) }\end{array}$ & 0,933 & 0,905 & 0,777 & 0,323 & 0,203 & 0,882 & & & \\
\hline $\begin{array}{l}\text { Interactive Control S. } \\
\text { (ICS) }\end{array}$ & 0,937 & 0,912 & 0,789 & 0,206 & 0,011 & 0,559 & 0,888 & & \\
\hline Belief Systems (BS) & 0,940 & 0,914 & 0,795 & 0,354 & 0,106 & 0,635 & 0,786 & 0,892 & \\
\hline Boundary Systems (LS) & 0,936 & 0,914 & 0,784 & 0,128 & $-0,021$ & 0,618 & 0,500 & 0,496 & 0,886 \\
\hline
\end{tabular}

Source: Research data. 
According to Table 1, all AVE loads are statistically significant as the values of each latent variable are above the limit value of 0.50. Therefore, the latent variables explain more than half of the variance of their indicators (HAIR JUNIOR, BLACK, BABIN et al., 2009). Regarding the results of Composite Reliability and Cronbach's Alpha coefficients, which are intended to test the reliability of the model, both coefficients are higher than the minimum value 0.70 , as recommended by Hair Junior, Black, Babin et al. (2009).

There is discriminant validity between the constructs as all indicators showed higher factor loads in their respective latent variables (HAIR JUNIOR, BLACK, BABIN et al., 2009), for example, individual creativity (0.780). There is no correlation between the latent variables of the first order, which exceed in magnitude the square root of the AVE of the related latent variables (HAIR JUNIOR, BLACK, BABIN et al., 2009). For example, the highest value of individual creativity was for work performance (0.569), but it was lower than their respective AVE (individual creativity $=0.608$ and work performance $=0.718$ ).

\section{Structural model}

After verifying the adequacy of the structural model, the structural equations were estimated by means of bootstrapping analysis, a technique adopted to test the significance of the relationships between the latent variables used in the study (HAIR JUNIOR, HULT, RINGLE et al., 2014). Table 2 shows the relations of the estimated coefficients of the structural model (direct, indirect and total effect), the levels of significance, the Variance Accounted For (VAF) and the result of the test of the research hypotheses.

Table 2

Results of the structural model

\begin{tabular}{|c|c|c|c|c|c|c|c|c|c|c|c|}
\hline \multirow{3}{*}{$\begin{array}{l}\text { Description } \\
\begin{array}{l}\text { Diagnostic Control S. } \rightarrow \\
\text { Individual Creativity }\end{array}\end{array}$} & \multicolumn{2}{|c|}{$\begin{array}{l}\text { Unmediated } \\
\text { model }\end{array}$} & \multicolumn{9}{|c|}{ Mediated model } \\
\hline & \multirow{2}{*}{$\begin{array}{c}\text { Struc } \\
\text { Coeff }\end{array}$} & \multirow{2}{*}{$\begin{array}{c}\mathrm{P} \\
\text { Value } \\
-\end{array}$} & \multirow{2}{*}{$\begin{array}{l}\text { Direct } \\
\text { Effect }\end{array}$} & \multirow{2}{*}{$\begin{array}{c}\text { P } \\
\text { Value } \\
0,088\end{array}$} & \multirow{2}{*}{$\begin{array}{c}\text { Indirect } \\
\text { Effect } \\
-\end{array}$} & \multirow{2}{*}{$\begin{array}{c}\mathrm{P} \\
\text { Value } \\
-\end{array}$} & \multirow{2}{*}{\begin{tabular}{|c|}
$\begin{array}{c}\text { Total } \\
\text { Effect }\end{array}$ \\
$-0,190$
\end{tabular}} & \multirow{2}{*}{$\begin{array}{c}\mathrm{P} \\
\text { Value } \\
0,088\end{array}$} & \multirow{2}{*}{$\begin{array}{c}\text { Mediation } \\
\text { (VAF) } \\
-\end{array}$} & \multicolumn{2}{|c|}{ Hypothesis } \\
\hline & & & & & & & & & & $\mathrm{H}_{1}$ & Rejected \\
\hline $\begin{array}{l}\text { Diagnostic Control S. } \rightarrow \\
\text { Work Performance }\end{array}$ & 0,002 & 0,989 & $-0,074$ & 0,405 & $-0,108$ & 0,092 & $-0,182$ & 0,127 & - & $\mathrm{H}_{3}$ & Rejected \\
\hline $\begin{array}{l}\text { Interactive Control S. } \rightarrow \\
\text { Individual Creativity }\end{array}$ & - & - & 0,411 & 0,002 & - & - & 0,411 & 0,002 & - & $\mathrm{H}_{1}$ & Accepted \\
\hline $\begin{array}{l}\text { Interactive Control S } \rightarrow \\
\text { Work Performance }\end{array}$ & 0,000 & 0,999 & $-0,105$ & 0,393 & 0,234 & 0,004 & 0,129 & 0,247 & - & $\mathrm{H}_{3}$ & Rejected \\
\hline $\begin{array}{l}\text { Belief Systems } \rightarrow \\
\text { Individual Creativity }\end{array}$ & - & - & 0,253 & 0,010 & - & - & 0,253 & 0,010 & - & $\mathrm{H}_{1}$ & Accepted \\
\hline $\begin{array}{l}\text { Belief Systems } \rightarrow \\
\text { Work Performance }\end{array}$ & 0,382 & 0,008 & 0,210 & 0,062 & 0,144 & 0,010 & 0,355 & 0,006 & 0,289 & $\mathrm{H}_{3}$ & $\begin{array}{l}\text { Partially } \\
\text { Accepted }\end{array}$ \\
\hline $\begin{array}{l}\text { Boundary Systems } \rightarrow \\
\text { Individual Creativity }\end{array}$ & - & - & $-0,137$ & 0,206 & - & - & $-0,137$ & 0,206 & - & $\mathrm{H}_{1}$ & Rejected \\
\hline $\begin{array}{l}\text { Boundary Systems } \rightarrow \\
\text { Work Performance }\end{array}$ & $-0,277$ & 0,023 & $-0,135$ & 0,073 & $-0,078$ & 0,228 & $-0,214$ & 0,031 & - & $\mathrm{H}_{3}$ & Rejected \\
\hline $\begin{array}{l}\text { Individual Creativity } \rightarrow \\
\text { Work Performance }\end{array}$ & - & - & 0,571 & 0,000 & - & - & 571 & 0,000 & - & $\mathrm{H}_{2}$ & Accepted \\
\hline$R^{2}$ & \multicolumn{2}{|c|}{ WP: 0,093 } & \multicolumn{9}{|c|}{ IC: 0,170 and WP: 0,358} \\
\hline
\end{tabular}

Source: Research data.

Through the coefficients of determination $\left(R^{2}\right)$, individual creativity is explained in $17.0 \%$ and work performance in $35.8 \%$ through the model with mediation. In previous studies, low values for $R^{2}$ of creativity and work performance were observed when related to the MCSs. As for the creativity variable, the highest $R^{2}$ found was in the study carried out by Moulang (2015), 
with 0.226. Regarding the performance variable, the highest $R^{2}$ found was in the study conducted by Hall (2008), with 0.529. Thus, the $R^{2}$ of this study is considered valid, since the values were close to the values found in previous studies.

In the results of the relationships, the direct effect represents the direct relationship between the exogenous (work performance), mediator (individual creativity) and endogenous (work performance) variable in the model. The indirect effect represents the relationship between the exogenous (MCS) and endogenous (work performance) variables through the mediator (individual creativity) in the construction of the structural equation model. The total effect is the sum of the direct effect and the indirect effect between the exogenous (MCS) and endogenous (work performance) variables in the PLS structural equation model (HAIR JUNIOR, BLACK, BABIN et al., 2009).

It was noticed that interactive and belief control systems have a direct positive effect on individual creativity, while diagnostic control systems have a negative effect. Only belief systems had a direct positive effect on work performance. The boundary systems had a direct negative effect on work performance. Lastly, individual creativity also had a direct positive effect on work performance.

Regarding indirect effects, diagnostic, interactive and belief control systems have indirect effect on work performance through the mediation of individual creativity. However, if the direct relationship between the exogenous and endogenous variables is not significant, there is no point in analyzing the indirect effect through mediation (HAIR JUNIOR, BLACK, BABIN et al., 2009). Considering the total effect, it can be said that the interactive and belief control systems are positively related to individual creativity, while the diagnostic control systems are negatively related to it. Furthermore, belief systems and individual creativity are positively related to performance, while boundary systems are negatively related to work performance.

\section{ANALYSIS OF THE HYPOTHESES AND DISCUSSION OF THE RESULTS}

Hypothesis $\mathrm{H}_{1}$ predicts a positive relationship between the MCSs and individual creativity, thus, based on the results, $\mathrm{H}_{1}$ is accepted for interactive and belief control systems. The interactive and belief control systems positively influence the individual creativity of managers. These results corroborate the research conducted by Moulang (2015), that analyzed the interactive use of the MCSs and found a positive relationship with individual creativity; and by Speklé, Van Elten and Widener (2017), that analyzed the four levers jointly.

Simons (1995) proposed that organizations need new and different types of control systems to empower employees and foster creative thinking and innovative activities. In this sense, Speklé, Van Elten and Widener (2017) observed that the more intensively the levers of the MCSs are used, the clearer control becomes in organizations, providing additional motivation for employees to be creative in their tasks. Moulang (2015) found out that the MCSs have the potential to encourage individuals' creativity, providing useful feedback information and aligning the individuals' behavior with the organizational goals.

Positively, belief systems enable and motivate managers to take initiative searching for opportunities, making decisions and in solving problems in a manner consistent with the organization's values, fostering creative behavior (SIMONS, 1995). The positive and significant relationship found in this study between belief systems and individual creativity, with a path coefficient of 0.253 , supports what is recommended in the literature.

Interactive control systems can stimulate creativity and product innovation, offer guidance, trigger initiatives and provide legitimacy (BISBE and OTLEY, 2004). Therefore, the positive and significant relationship found out in this study between interactive control systems and individual creativity, with a path coefficient of 0.396 , corroborates the results of research published in the literature (BISBE and OTLEY, 2004), that interactive control systems encourage managers to seek strategic and creative opportunities.

However, the diagnostic control systems and boundary systems showed a significant and non-significant negative relationship, respectively, so $\mathrm{H}_{1}$ is rejected for these variables. Diagnostic control systems are used to motivate, monitor and reward the achievement of goals, while boundary systems are used to establish limits for the organization's members (SIMONS, 1995). Both act as factors that restrict the behavior of employees and represent a negative force (SIMONS, 1995). Thus, the negative 
sign of the relationship between these systems and individual creativity is justified by restricting the creativity of the managers in their activities.

Hypothesis $\mathrm{H}_{2}$ predicts a positive relationship between individual creativity and work performance. The results reveal that individual creativity is positively related to work performance, with a significance level of $1 \%$, and with a path coefficient of 0.567. This indicates that creative managers, through new ideas, are able to enhance their activities, reducing the difficulties to carry out their tasks. The results confirm $\mathrm{H}_{2}$ and corroborate the studies carried out by Gong, Huang and Farh (2009), Zhang and Bartol (2010) and Bodla and Naeem (2014).

Gong, Huang and Farh (2009), through hierarchical regression, found a positive and significant relationship between employee's creativity and work performance, indicating that creative individuals can improve procedures or processes to increase their efficiency. Zhang and Bartol (2010), through non-linear regression, found a positive and significant relationship between creative performance and overall work performance, indicating that, in order to perform complex tasks better, managers need to incorporate new ideas. Bodla and Naeem (2014), through modeling structural equations, found a positive and significant direct effect relationship between creative performance and the volume of individual sales, indicating that creative salespeople are able to capture the customer's need.

Lastly, hypothesis $\mathrm{H}_{3}$ postulates that there is a positive relationship between the MCSs and work performance, mediated by individual creativity. The results suggest that belief systems are positively related to work performance, with a significance level of $1 \%$, and that individual creativity has a partial effect between the two variables, since the VAF was 0.289 . According to Hair Junior, Black, Babin et al. (2009), with a VAF value above 0.8 mediation is complete, between 0.2 and 0.8 mediation is partial and with values lower than 0.2 there is no mediation. Thus, $\mathrm{H}_{3}$ was partially confirmed for belief systems, since mediation was partial. This result differs from the study conducted by Webster (2006), which found out no relationship between the interactive use of the MCSs and work performance, mediated by creativity, which instigates additional research.

As for boundary systems, the relationship was negative and significant with work performance. Therefore, hypothesis $\mathrm{H}_{3}$ is rejected for this variable. Boundary systems establish the rules of the game and identify actions and pitfalls that employees must avoid, that is, they act as a restriction to the managers' actions (SIMONS, 1995). These restrictions can impair the performance of managers because, when their activities are limited in a certain way, they can make decisions that they would not like to make, impairing their performance at work.

The non-significance of the relationship between diagnostic and interactive control systems with work performance may indicate two assumptions. First, in diagnostic control systems, managers require clear communication from the company on how to perform their work, so that they can adjust their routine and obtain benefits from the use of the MCSs. Regarding the interactive control systems, they clearly understand that the execution of their tasks can be adjusted or reorganized according to the needs to better fulfill the objectives. Thus, the non-significant relationship can be justified by the balance of both control levers (diagnostic / interactive) in the companies surveyed.

It is noteworthy that the interactive and belief control systems influence individual creativity, just as creativity influences work performance, in addition to being a partial mediator between belief systems and work performance. This suggests that interactive control systems encourage managers to be creative in conducting their activities, and belief systems enable and motivate them to solve existing problems in the organization, promoting creativity (SIMONS, 1995). Belief systems improve the performance of the managers, thus helping to solve the organization's problems (SIMONS, 1995); and creativity partially helps in the relationship between both, since it reduces the difficulties to carry out the tasks in the organization (GONG, HUANG and FARH, 2009). 


\section{CONCLUSIONS}

This study analyzed the influence of the management control systems on work performance, mediated by individual creativity. The research results provide support for Simons' (1995) propositions regarding the relevance of interactive and belief control systems in fostering managers' individual creativity. These two systems are necessary to empower managers and allow creativity to flourish in their actions, assisting in the conduction of the tasks in the organization, which supports hypothesis $\mathrm{H}_{1}$ and corroborates the studies conducted by Moulang (2015) and Speklé, Van Elten and Widener (2017).

The results indicate that individual creativity positively influences work performance. Creative managers are able to enhance their activities and improve their performance at work, which highlights the importance of managers coming up with creative ideas. Therefore, the results confirm hypothesis $\mathrm{H}_{2}$ and are consistent with the results found out by Gong, Huang and Farh (2009), Zhang and Bartol (2010) and Bodla and Naeem (2014).

It is also observed that belief systems positively influence work performance, and that individual creativity partially helps in the relationship between both. Belief systems are used by organizations to inspire the search for new opportunities, encouraging managers to do their best in their tasks in the organization, improving their performance. In addition, they encourage individual creativity, which partially mediates both, thus partially accepting $\mathrm{H}_{3}$.

It is concluded based on the results that the MCSs in the organizations surveyed exert influence on individual creativity and work performance. It is emphasized, specifically, that the interactive and belief control systems influence individual creativity, just as creativity influences work performance, in addition to being a partial mediator between belief systems and work performance.

The study contributes to the literature by jointly addressing Simons' levers, individual creativity and work performance in industrial companies considered innovative in Brazil, even though previous studies have already analyzed the relationship between Simons' levers and individual creativity (MOULANG, 2015; SPEKLÉ, VAN ELTEN and WIDENER, 2017). Regarding the companies' daily practice, this study also contributes by highlighting the importance of individual creativity in the performance of managers, mainly through the partial mediation of the relationship between belief systems and work performance.

Among the limitations, it is noteworthy that this study focused on the positive effect of individual creativity on the performance of managers, but it is possible that creativity has a negative effect, leading managers to engage in dishonest behaviors (GINO and ARIELY, 2012). Another limitation is in the research instruments since, although they have been extracted from previous studies, the assertions may not have fully captured the nature of the MCSs, individual creativity and performance at work.

As a possible outcome of this study, it is recommended to conduct longitudinal research that can provide empirical evidence of causality in the relationships between the constructs analyzed. Also, other mediation variables can be considered, such as individual's behavior, job satisfaction or role autonomy. It is also recommended that future research segregate the types of organizational structure into those that are more and less flexible, and can be understood as more or less bureaucratic, to verify eventual differences. 


\section{REFERENCES}

ADLER, P. S.; CHEN, C. X. Combining creativity and control: Understanding individual motivation in large-scale collaborative creativity. Accounting, Organizations and Society, v. 36, n. 2, p. 63-85, 2011.

AMABILE, T. M. The social psychology of creativity: A componential conceptualization. Journal of Personality and Social Psychology, v. 45 , n. 2, p. 357, 1983.

ANTHONY, R. Planning and control systems: a framework for analysis. Division of Research, Graduate School of Business Administration, Harvard University. Boston: Harvard University, 1965.

BISBE, J.; OTLEY, D. The effects of the interactive use of management control systems on product innovation. Accounting, Organizations and Society, v. 29, n. 8, p. 709-737, 2004.

BODLA, M. A.; NAEEM, B. Creativity as mediator for intrinsic motivation and sales performance. Creativity Research Journal, v. 26, n. 4, p. 468-473, 2014.

BURNEY, L.; WIDENER, S. K. Strategic performance measurement systems, job-relevant information, and managerial behavioral responses - role stress and performance. Behavioral Research in Accounting, v. 19, n. 1, p. 43-69, 2007.

CHIN, W. W. The partial least squares approach for structural equation modelling. In: MARCOULIDES, G. A. (Ed.). Modern methods for business research. New York: Lawrence Erlbaum, 1998. p. 295-336.

DAVILA, A.; FOSTER, G.; OYON, D. Accounting and control, entrepreneurship and innovation: Venturing into new research opportunities. European Accounting Review, v. 18, n. 2, p. $281-$ 311, 2009.

DENISON, D. R.; HOOIJBERG, R.; QUINN, R. E. Paradox and performance: Toward a theory of behavioral complexity in managerial leadership. Organization Science, v. 6, n. 5, p. 524-540, 1995.

GEORGE, J. M.; ZHOU, J. Understanding when bad moods foster creativity and good ones don't: the role of context and clarity of feelings. Journal of Applied Psychology, v. 87, n. 4, p. 687, 2002.

GILSON, L. L. Why be creative: A review of the practical outcomes associated with creativity at the individual, group, and organizational levels. In: ZHOU, J.; SHALLEY, C. (Eds.). Handbook of Organizational Creativity. New York: Lawrence Erlbaum, 2008. p. 303-322.

GINO, F.; ARIELY, D. The dark side of creativity: original thinkers can be more dishonest. Journal of Personality and Social Psychology, v. 102, n. 3, p. 445, 2012.

GONG, Y.; HUANG, J.-C.; FARH, J.-L. Employee learning orientation, transformational leadership, and employee creativity: The mediating role of employee creative self-efficacy. Academy of Management Journal, v. 52, n. 4, p. 765-778, 2009.

HAIR JUNIOR, J. F. et al. Análise multivariada de dados. Porto Alegre: Bookman, 2009.
HAIR JUNIOR, J. F. et al. Primer on Partial Least Squares Structural Equation Modeling (PLS-SEM). Los Angeles: Sage, 2014.

HALL, M. The effect of comprehensive performance measurement systems on role clarity, psychological empowerment and managerial performance. Accounting, Organizations and Society, v. 33, n. 2-3, p. 141-163, 2008.

HALL, M. Do comprehensive performance measurement systems help or hinder managers' mental model development? Management Accounting Research, v. 22, n. 2, p. 68-83, 2011.

HENRI, J.-F. Management control systems and strategy: A resourcebased perspective. Accounting, Organizations and Society, v. 31, n. 6, p. 529-558, 2006.

MARGINSON, D. et al. Examining a positive psychological role for performance measures. Management Accounting Research, v. 25, n. 1, p. 63-75, 2014.

MERCHANT, K. A.; VAN DER STEDE, W. A. Management control systems: performance measurement, evaluation and incentives. 4. ed. New York: Pearson, 2017

MOULANG, C. Performance measurement system use in generating psychological empowerment and individual creativity. Accounting \& Finance, v. 55, n. 2, p. 519-544, 2015.

RINGLE, C. M.; SILVA, D.; BIDO, D. Z. Modelagem de equações estruturais com utilização do SmartPLS. Revista Brasileira de Marketing, v. 13, n. 2, p. 56-73, 2014.

SIMONS, R. Levers of control: how managers use innovative control systems to drive strategic renewal. Boston: Harvard Business School, 1995.

SPEKLÉ, R. F.; VAN ELTEN, H. J.; WIDENER, S. K. Creativity and control: A paradox-Evidence from the levers of control framework. Behavioral Research in Accounting, v. 29, n. 2, p. 73-96, 2017.

WEBSTER, C. An empirical analysis of the relationships between the interactive use of performance measurement systems, creativity and performance: the intervening role of psychological empowerment. In: ANNUAL CONGRESS OF THE EUROPEAN ACCOUNTING, 29., 2006, Dublin. Proceedings... Brussels: European Accounting Association, 2006.

WIDENER, S. K. An empirical analysis of the levers of control framework. Accounting, Organizations and Society, v. 32, n. 7-8, p. 757-788, 2007.

ZHANG, X.; BARTOL, K. M. The influence of creative process engagement on employee creative performance and overall job performance: A curvilinear assessment. Journal of Applied Psychology, v. 95, n. 5, p. $862,2010$.

ZHOU, J.; SHALLEY, C. E. Expanding the scope and impact of organizational creativity research. In: ZHOU, J.; SHALLEY, C. (Eds.). Handbook of Organizational Creativity. New York: Lawrence Erlbaum, 2008. p. 347-368. 
Itzhak David Simão Kaveski

ORCID: https://orcid.org/0000-0001-8691-9904

Ph.D. in Accounting from the Universidade Federal de Santa Catarina (UFSC); Professor at Universidade Federal de Mato Grosso do Sul (UFMS),

Corumbá - MS, Brazil. E-mail: itzhak.konoha@gmail.com

\section{Ilse Maria Beuren}

ORCID: https://orcid.org/0000-0003-4007-6408

Ph.D. in Controllership Accounting from the Universidade de São Paulo (FEA/USP); Professor in the Post-Graduate Accounting Program at Universidade

Federal de Santa Catarina (UFSC), Florianópolis - SC, Brazil. E-mail: ilse.beuren@gmail.com 